\title{
A forske med kunsten som metodologisk praksis med aesthesis som mandat
}

\author{
Tone Pernille Østern* \\ NTNU Norges teknisk-naturvitenskapelige universitet
}

\section{Sammendrag}

Kunst, estetiske praksiser og forskningsmetodologier er hele tiden i bevegelse og tilblivelse. I artikkelen forsøker jeg delvis å finne noen stabiliseringspunkt for det å forske med kunsten gjennom å knytte an til et bredt kvalitativt og post-kvalitativt forskningsfelt. Samtidig lokaliserer jeg propeller som gir særlig drivkraft, motstand og retning for de metodologiske valgene man tar når man forsker med kunsten. Forskningsspørsmålet som har vokst fram gjennom arbeidet med artikkelen, er: Hvordan kan det å forske med kunsten som metodologisk praksis få form og drivkraft gjennom å forstå aesthesis som mandat? Som svar skriver jeg fram det å forske med kunsten som en menings- og mulighetssøkende, produktiv og etisk metodologisk praksis, der særlig form, mening, nærhet, kropp, kontekst, etikk og diversitet fungerer som metodologiske propeller.

Nøkkelord: Metodologi; å forske med kunsten; praksisledet forskning; kunstnerisk forskning

\begin{abstract}
Art, aesthetic practices and research methodologies are in a constant state of becoming and movement. In this article, I seek to find some stabilizing frames for research with the arts through connecting to a broad qualitative and post-qualitative research field. At the same time, I seek to localize propellers that particularly give momentum, resistance and direction for methodological choices when researching the arts. The research question that has taken shape through the work with the article is: How can research with the arts as methodological practice be given frames and momentum through understanding aesthesis as its mandate? As an answer, I posit research with the arts as a meaning-seeking, productive and ethical methodological practice, where particularly the aspects of form, meaning, nearness, body, context, ethics and diversity function as methodological propellers.
\end{abstract}

Key concepts: Methodology; research with the arts; practice-led research; artistic research Received: August, 2017; Accepted: November, 2017; Published: December, 2017

^Korrespondanse: Tone Pernille Østern, Institutt for lærerutdanning, NTNU 7491 Trondheim. Epost: tone.pernille.ostern@ntnu.no 


\section{T. Pernille Østern}

Det å forske med kunsten karakteriseres av at det ofte er kunstnerens eller kunstpedagogens egen erfaring og praksis som er utgangspunkt for forskningsarbeidet. Det foreligger en nærhet og et innenfrablikk til det som skal undersøkes, og det å forske med kunsten er en form for forskning som er orientert mot mening, fortolkning, forståelse og endring. Å forske med kunsten er et felt som utfordrer forskningens verbalspråklige dominans, og som peker på andre alternativer for erkjennelse, opplevelse, transformasjon, læring, kunnskapsproduksjon, forståelse og forskningsformidling. I forskning som ofte designes som flersanselige og interdisiplinære flettverk, skal metodologier skapes av kunstnere, kunstpedagoger og andre som forsker med kunsten.

\section{Innramming}

Med metodologi mener jeg i denne artikkelen en kreativ, kompleks, krevende og kritisk prosess som innbefatter alle de valg man tar som forsker. Jeanette Redding-Jones (2005) beskriver metodologi som hele prosessen med hvordan forskeren gjør undersøkelser. Slik jeg bruker begrepet her, rommer det både forskerens tenkning, sansning, opplevelser, praktisk-kunstneriske arbeid og tekstarbeid, alle valg og all håndtering av etiske dilemmaer knyttet til prosessen. Metodologi forstår jeg dermed som en prosess, selv om metodologi kan framstå som et produkt i etterkant, når prosjektet er beskrevet og avsluttet. Det er dette metodologiske nivået jeg fokuserer på i artikkelen. Det metodologiske nivået ligger under det vitenskapsteoretiske nivået, og over det metodiske nivået (Savin Baden \& Howell Major, 2013, s. 47). Det vitenskapsteoretiske nivået handler - helt kort - om det filosofiske synet på kunnskap som forskeren er posisjonert i. Det metodiske nivået handler om hvilke konkrete metoder forskeren bruker for å generere eller analysere materiale (Savin Baden \& Howell Major, 2013; Østern \& Letnes, 2017). Denne artikkelen vil fokusere på nivået midt i mellom, det metodologiske.

Jeg har over tid hatt (og har) to yrkesroller: som koreograf på det frie scenekunstfeltet fra år 2000, og som kunstfagdidaktiker ved universitet fra år 2009. Disse rollene har etter hvert blandet seg sammen: Koreografen som utforsker og veileder på det frie scenekunstfeltet har krysset seg med kunstfagdidaktikeren som forsker og veileder innenfor en universitetsstruktur. Jeg har, med en fot i ulike organisatoriske leirer, forsket og veiledet både kunstnerisk og vitenskapelig. Denne tofotet-heten har vært og er produktiv, og det kunstneriske og det vitenskapelige har flettet og fletter seg helt og holdent sammen.

I mitt arbeid ved universitetet har jeg jobbet med studenter fra et bredt profesjonsrettet felt. Det har gitt meg kjennskap til kvalitativ forskning generelt og til det å forske med kunsten spesielt, og jeg ser dette som et spekter og ikke noe som står adskilt fra hverandre. Det har, kanskje særlig i Norge, blitt gjort forsøk på å forstå kunstnerisk forskning som noe helt annerledes enn og autonomt fra annen kvalitativ forskning, litt på samme måte som enkelte kunstneriske tradisjoner ønsker å holde kunstnerens autonomi i hevd (jf. Roar, 2016). Fra mitt ståsted kan jeg ikke se denne adskiltheten, og jeg kan heller ikke se verdien i en slik adskillelse. Det er isteden svært mye som er 
sammenfallende i kvalitativ, praksisledet og kunstnerisk forskning. I denne artikkelen er min hensikt å gi det å forske med kunsten metodologisk stabilitet nettopp giennom å trekke paralleller til et bredere felt for kvalitativ og post-kvalitativ forskning. Samtidig peker jeg på at det er noen aspekter som er særlig framtredende når metodologier for å forske med kunsten skal skapes. Disse kaller jeg metodologiske propeller, som gir særlig drivkraft, retning og motstand når man forsker med kunst.

\section{Kontekstualisering $i$ et internasjonalt fagfellesskap}

Det å forske med kunsten er et felt som vekker stor interesse og er i sterk utvikling, men som samtidig er eksplorerende og utprøvende. Kompleksiteten ved og interessen for slik forskning kommer av at det å forske med kunsten er forskning som kjennes og leves, som berører og affekterer, som er personlig og nær og som ofte får i stand endring, ikke minst hos forskere og forskningsdeltakere selv (Barone \& Eisner, 2012; Bresler, 2006; Sinner, Leggo, Irwin, Gouzouasis \& Grauer, 2006). I dette ligger både kraften, potensialet og utfordringene til det å forske med kunst.

Internasjonalt har det de seneste tiårene vært en eksplosiv utvikling innenfor det som på engelsk har mange navn og varianter, blant annet artistic research, arts-based research, practice-led research, art as research, ARTography og performative research. I denne artikkelen brukes å forske med kunsten som et paraplybegrep for alle disse. Å utrede disse begrepene vil være tema for en egen artikkel. Her konsentrerer jeg meg om artsbased research og artistic research som kontekstualisering av feltet. Arts-based fordi det var det første begrepet som dukket opp, artistic research fordi dette begrepet har vært et mye brukt (og omdiskutert) begrep fra en gang på 1990-tallet og framover. Begrepet postkvalitativ forskning er også interessant, men av hensyn til avgrensning utelates en drøfting av kvalitativ vs post-kvalitativ forskning her (se Østern \& Letnes, 2017).

Man sted- og tidfester ofte utviklingen av arts-based research, i hvert fall forskning under det begrepet, til en kunstpedagogisk begivenhet under ledelse av Elliot Eisner ved Stanford universitet i USA i 1993 (Savin-Baden \& Howell Major, 2013, s. 288). Begivenheten ved Stanford er verdt å nevne som et slags startpunkt for når forskere virkelig begynte å tenke, også metodologisk, på det å forske med kunsten (selv om sammenfletting av kunst og vitenskap har langt eldre tradisjoner enn det, tilbake til et punkt der det ikke fantes noe egentlig skille mellom kunst og vitenskap). Herfra har feltet utviklet seg i forskningsmiliøer i ulike deler av verden. I 2012 definerer Tom Barone og Eisner arts-based research slik: «Arts based research is a process that uses the expressive qualities of form to convey meaning» (s. xii). Min omformulering av dette blir, som en første definisjon på det å forske med kunsten, at det å forske med kunsten kan forstås som en meningssøkende prosess der man aktivt tar $i$ bruk ulike formspråk og modaliteter.

Det å forske med kunsten har vist seg å være en svært produktiv tilnærming til forskning, som endrer både universitetsstrukturer og kunstfeltet selv. Mye kunstnerisk og kunst-basert forskning skjer på tvers av forskningsmiljøer ved universiteter og 


\section{T. Pernille Østern}

det frie kunstfeltet. Smith og Dean (2009) påpeker hvordan universitetsstrukturer er $i$ bevegelse på grunn av kunnskap generert gjennom kunstneriske og kreative prosesser - et synlig fenomen også i Norden.

Artistic research er et yngre begrep enn arts-based research, og det har ikke samme konnotasjon til kunstpedagogisk praksis. Internasjonalt har Finland, UK og Australia vært ledende i utvikling av kunstneriske doktorgradsprogrammer ${ }^{1}$ (Roar, 2016, s. 310), og i Norden var Finland første land ut med (det som nå er) Doctoral Programmes in the Arts fra $1988^{2}$. I Norge brukes når denne artikkelen skrives begrepet «kunstnerisk utviklingsarbeid», og i den norske Lov om universiteter og høgskoler har kunstnerisk utviklingsarbeid vært sidestilt med forskning siden $1995^{3}$.

Artistic research er ikke et enkelt begrep å definere, selv om begrepet i hvert fall internasjonalt begynner å finne sin plass. Andre akademiske disipliner har en lenger historie og har debattert for eksempel forholdet mellom praksis og teori over tid og stabilisert noen form for enighet, mens disse debattene fortsatt foregår når det gjelder artistic research (Academy of Finland, 2009, s. 22). The Performing Arts Research Centre ved UniArts Helsinki definerer i 2015 kunstnerisk forskning slik: "Artistic research is academic, multidisciplinary and collective research realised in the medium of art. ${ }^{4} \mathrm{Jeg}$ anbefaler interesserte å lese hvordan denne definisjonen blir utdypet (se fotnote 6). Her skal jeg peke på noen aspekter jeg mener er særlig sentrale ved kunstnerisk forskning.

Kunstnerisk forskning skjer gjennom kunst, eller som Mika Hannula, Juha Suoranta \& Tere Vadén (2014, s. xii) skriver: «artistic research happens inside-in». Kunstnerisk forskning er forskning der forskningsspørsmålet besvares gjennom kunstnerisk praksis. Med andre ord, i kunstnerisk forskning fungerer practice-as-research (Nelson, 2013). Man anerkjenner, som Per Roar (2016, s. 311) skriver, den inneboende kunnskapen som kunstnerisk praksis kan generere. Dette er likevel ikke enestående for artistic research, og jeg gjenkjenner practice-as-research som fullt ut til stede innenfor også ikke-kunstneriske praksiser i praksisledet profesjonsrettet kvalitativ forskning, som aksjonsforskning (Steen-Olsen \& Postholm, 2009) og intervensjonsforskning (Sannino, Engeström \& Lemos, 2016). Kunnskapsgenereringen skjer $i$ den praktiske (ut)forskningen. Dette er altså et kunnskapssyn kunstnerisk forskning deler med kvalitativ forskning generelt: Kunnskapingen kan skje $i$ praksis.

${ }^{1} \mathrm{Se}$ også ADiE Artistic Doctorates in Europe https://www.artisticdoctorates.com/ (tilgang 04.08.2017)

${ }^{2}$ Ved det som nå er UniArts Helsinki tilbys graden Dr. of Arts, Dr. of Dance, Dr. of Theatre og Dr. of Music http://www.uniarts.fi/en/doctoral-education (tilgang 22.10.2017). Forskningskoordinator Annika Fredrikson ved Konstuniversitetets Teaterhögskola oppgir i e-post at det som den gang var Teaterhögskolan fikk rett å bedrive jatkotutkinto, eller 3. syklus, i 1988. De ulike kunsthøyskolene ved det nå sammenslåtte UniArts Helsinki har hatt litt ulik veg mot høyskole/universitetsstatus, men alle fikk sine første doktorer i respektive teaterkunst, dansekunst, musikk og billedkunst i perioden 1990-2001. (e-postkorrespondanse med Fredrikson 07.11.2017)

${ }^{3}$ Program for kunstnerisk utviklingsarbeid http://artistic-research.no/?page_id=12 (tilgang 27.09.2013)

${ }^{4} \mathrm{Se} \quad$ http://www.uniarts.fi/sites/default/files/Tutke_mission_vision_2017_2020_en.pdf (tilgang 22.10.2017) 
Det andre sentrale aspektet jeg vil trekke fram ved kunstnerisk forskning, er at den har kvaliteter som giør at den oppleves som kunstnerisk, eller estetisk, erfaring. Julian Klein ${ }^{5}$ skriver om artistic research at:

$[\ldots]$ it has to be acquired through sensory and emotional perception, through the very artistic experience from which it cannot be separated [...] Artistic knowledge is, in each and every case, sensual and physical, «embodied knowledge.» The knowledge for which artistic research strives is a felt knowledge.

Også artografisk forskning (der ARTografi står for den sammenflettede posisjonen som Artist-Researcher-Teacher) og arts-based forskning framhever estetisk eller kunstnerisk erfaring som helt sentralt (jf. Sinner et al, 2006; Rasmussen, 2012). Det er levd forskning som sanses, kjennes, og som berører.

Et tredje sentralt aspekt er at kunstnerisk forskning har en transformativ karakter. Det er ikke hovedsakelig forskning som forsøker å beskrive og forklare, men som forsøker å forstå, fortolke, peke på meningsskaping, skape aktivitet og bidra til endring. Dette kan være endring i kunsten selv, hos ulike deltakere i kunstaktiviter, i utdanningseller andre profesjonskontekster, og på mikro- og makronivå i lokale og samfunnsmessige kontekster. The Performing Arts Research Centre ved UniArts Helsinki skriver:

The knowledge generated by artistic research aims at changes in art: it generates new kind of art, novel means for art-making and implementing artistic practices, and new understanding on the significance. Further, it affects the manner we perceive and experience ourselves, one another, and the universe. ${ }^{6}$

Dette endringsorienterte aspektet deler kunstnerisk forskning også med profesjonsrettet forskning som aksjonsforskning, designorientert forskning og innovasjonsforskning. Liora Bresler $(1994 ; 2006)$ kaller dette formative research - formende forskning.

Det fjerde aspektet ved kunstnerisk forskning jeg vil trekke fram, er at for å kalle noe kunstnerisk forskning, bør det være en aktivitet som skjer i tilknytning til en (kunst)høyskole eller -universitet (jf. Hannula, Suoranta \& Vadén, 2014; Roar, 2016; Ölme, 2017). The Performing Arts Research Centre ved UniArts Helsinki skriver:

The academic nature of artistic research means that research generates knowledge that is based on experience, is justifiable and that can be assessed with academic criteria. $^{7}$

Det siste aspektet jeg vil peke på er at kunstnerisk forskning ikke er identisk med det å skape kunst, men handler om å ta for seg problemområder og forskningsspørsmål som undersøkes gjennom eller i kunst. Hannula, Suoranta \& Vadén (2014, s. xi) skriver: «artistic research $\neq$ art and art-making». På dansekunstfeltet er «research» et begrep det har gått inflasjon $\mathrm{i}, \mathrm{og}$ ordet brukes i dag ofte der man for 10 år siden kanskje hadde brukt begrepet undersøke eller utforske. Men kunstnerisk forskning er ikke det samme som

${ }^{5}$ Lastet fra http://www.jar-online.net/what-is-artistic-research/ (02.08.2017)

${ }^{6} \mathrm{Se} \quad$ http://www.uniarts.fi/sites/default/files/Tutke_mission_vision_2017_2020_en.pdf (tilgang 22.10.2017)

${ }^{7} \mathrm{Se} \quad$ http://www.uniarts.fi/sites/default/files/Tutke_mission_vision_2017_2020_en.pdf (tilgang 22.10.2017) 


\section{T. Pernille Østern}

kunstnerisk utforskning og kreativitet, noe som inngår i all kunst. Det er forskjell på å utforske og å forske (jfr. Hannula, Suoranta \& Vadén, 2014; Orning, 2017; Raes, 2014).

Slik jeg bruker begrepet kunstnerisk forskning i denne artikkelen, er det noe som skjer innenfor eller i kontakt med en akademisk ramme og som forholder seg til etiske retningslinjer, metodologisk refleksivitet, teori, transparens og kritikk, dokumentasjon og publikasjon i noen form, samt som har referanser til, går i dialog med, formidles blant og kan kritiseres av fagfeller.

Sammenfattende er altså det å forske med kunsten et felt som har stor kompleksitet og diversitet, og som er eksplorerende og utprøvende. Feltet samles likevel av noen sentrale aspekter som er forsøkt berørt i denne kontekstualiseringen. Feltet samles også av at det får sitt mandat gjennom aesthesis - det sanselige.

\section{Aesthetis som mandat for det å forske med kunsten}

Det å forske med kunsten hviler på aesthesis, som kommer fra det greske ordet aisthêtikos, og betyr omtrent å 'sanse' (Oxford dictionary ${ }^{8}$ ). Estetiske prosesser er i sin brede definisjon prosesser der verden sanses, oppleves, kjennes og blir mulig å dele av og mellom mennesker: mennesker som alltid er sansende, opplevende og relasjonelle. Estetiske prosesser har i denne brede definisjonen enorm betydning for menneskelig liv, viten og livskvalitet. Motsatsen er anestesi - å være bedøvet, avskåret fra sine sanser og dermed fra opplevelser. Kunst oppstår et sted i forholdet mellom aesthesis og samfunn, og kunstens oppgave kan forstås som både å etablere og utfordre dette forholdet. ${ }^{9}$ Kunst og estetiske prosesser tilfører en følelse av berøring. Å forske med kunsten kan derfor gi en følelse av at forskningsprosessen og -oppdagelsene rører ved noe i meg. Dette er karakteristisk for kvalitativ forskning som sådan, men kunsten spiller på multimodale strenger og løfter berøring og provokasjon i forgrunnen. Kunst vekker affekt.

Her oppstår en produktiv kollisjon mellom kunst og et tradisjonelt syn på forskning, særlig mellom kunst og positivismen som ved inngangen til 1900-tallet hadde festet røttene dypt i forskningens selvforståelse. I slik forståelse er forskning objektiv, adskilt fra forskerens kropp, affekter, situasjoner, sammenhenger, kultur og erfaringer. I 2017 er både verden og forskningen for lengst destabilisert med andre, post-positivistiske vitenskapsteoretiske forståelser, men fortsatt er disse røttene snubletråder for aksept og verdsetting av det å forske med kunsten. For å fortsette å luke

\footnotetext{
${ }^{8}$ http://www.oxforddictionaries.com/definition/english/aesthetic (tilgang 24.09.13)

${ }^{9}$ Doktogradsprogrammet i kunstnerisk forskning ved UniArts Helsinki definerte aesthesis og kunstens mandat slik på sine websider i 2013: «Aesthesis [...] refers to those primary processes that might be broadly described as aesthetic and in which and through which the world makes itself known and knowable, experienceable and shareable. The question of the relationship between society and aesthesis, as well as of establishing and altering that relationship, is the question of art. Inasmuch as art is a shared concern [...] it also becomes [...] a public affair, a res publica.» http://www.teak.fi/ About_the_programme (tilgang 27.09.2013)
} 
opp i disse positivistiske røttene på et bredt forskningsfelt, fungerer det å forske med kunsten både produktivt og kritisk. Det å forske med kunsten kan bringe fram forståelser som andre tilnærminger ikke klarer (jfr. Hannula, Suoranta \& Vadén, 2014).

Kunstens oppgave ser jeg som å stille seg i, og bli værende i, spørsmålet om forholdet mellom menneske, samfunn og aesthetis, og også påvirke, utvikle og endre dette forholdet. Det å forske med kunsten handler ut fra et slikt kunstsyn, i sin bredeste definisjon, om å undersøke, forstå, uttrykke og videre påvirke, endre og utvikle menneskelig, kulturell og/eller samfunnsmessig opplevelse, handling og erfaring på måter der kunstnerisk praksis på ett eller annet vis inngår (jf. Kara, 2015). Karakteristisk er at metodologier der kunst inngår, ofte er designet for å stimulere til flere og nye spørsmål enn til klare svar. Fokus er på utforskning, perspektivtaking, forståelse, meningsskaping, artikulasjon, endring og utvikling (jf. Kara, 2015; Savin-Baden \& Major, 2013).

\section{Det å forske med kunsten som metodologisk praksis}

Det er mange metodologiske aspekter man kan trenge å ta stilling til når man forsker med kunsten. De fleste av disse aspektene er sammenfallende med kvalitativ forskning generelt. I det følgende artikulerer og diskuterer jeg det jeg gjennom min erfaring som kunstner-forsker og veileder definerer som sentrale metodologiske stabiliseringspunkt når man forsker med kunsten. Se figur 1. Stabiliseringspunktene er gienkjennelige fra feltet for kvalitativ forskning.

Disse stabiliseringspunktene "propelleres» likevel, settes i bevegelse, på en særlig måte når man forsker med kunst, fordi kunstens mandat er aesthesis, det sanselige. Jeg mener altså at det finnes propeller som gir både særlige utfordringer og særlig drivkraft og retning, når man skal ta valg knyttet til de metodologiske stabiliseringspunktene når man forsker med kunsten. Jeg foreslår form, mening, nærhet, kropp, kontekst, etikk og diversitet som slike propeller som særlig påvirker de metodologiske overveielser man giør når man forsker med kunsten. Se figur 2.

I figur 2 lar jeg aesthesis være navet til det å forske med kunsten. Ut av navet vokser form, mening, nærhet, kropp, kontekst, etikk og diversitet som delaspekter av det sanselige. Aesthesis er mandatet, motoren; propellene er utløpere. Propellene gir drivkraft, retning og motstand i det en kunstner-forsker bygger sitt metodologiske puslespill, ulikt for hvert forskningsprosjekt. Disse propellene er ikke enestående for det å forske med kunsten, men de er særlig framhevet. Gjennom propellene inviteres aesthesis inn i hvert ledd av det å forske med kunsten.

I de følgende undertitlene behandler jeg de metodologiske stabiliseringspunktene jeg har definert. Hele tiden tenker jeg meg at overveielsene propelleres - får drivkraft, utfordres av og får retning av - form, mening, nærhet, kropp, kontekst, etikk og diversitet. Det formskapende er viktig i kunst - kunst peker grunnleggende på forholdet mellom innhold og form i ethvert uttrykk. Kunst er tett knyttet til meningsskaping. Kunst folder seg ut av kroppslige prosesser og kunnskaping. Kropp gir nærhet. Kontekstene som undersøkes er ofte små, nære. Dermed blir etiske krav store, og 


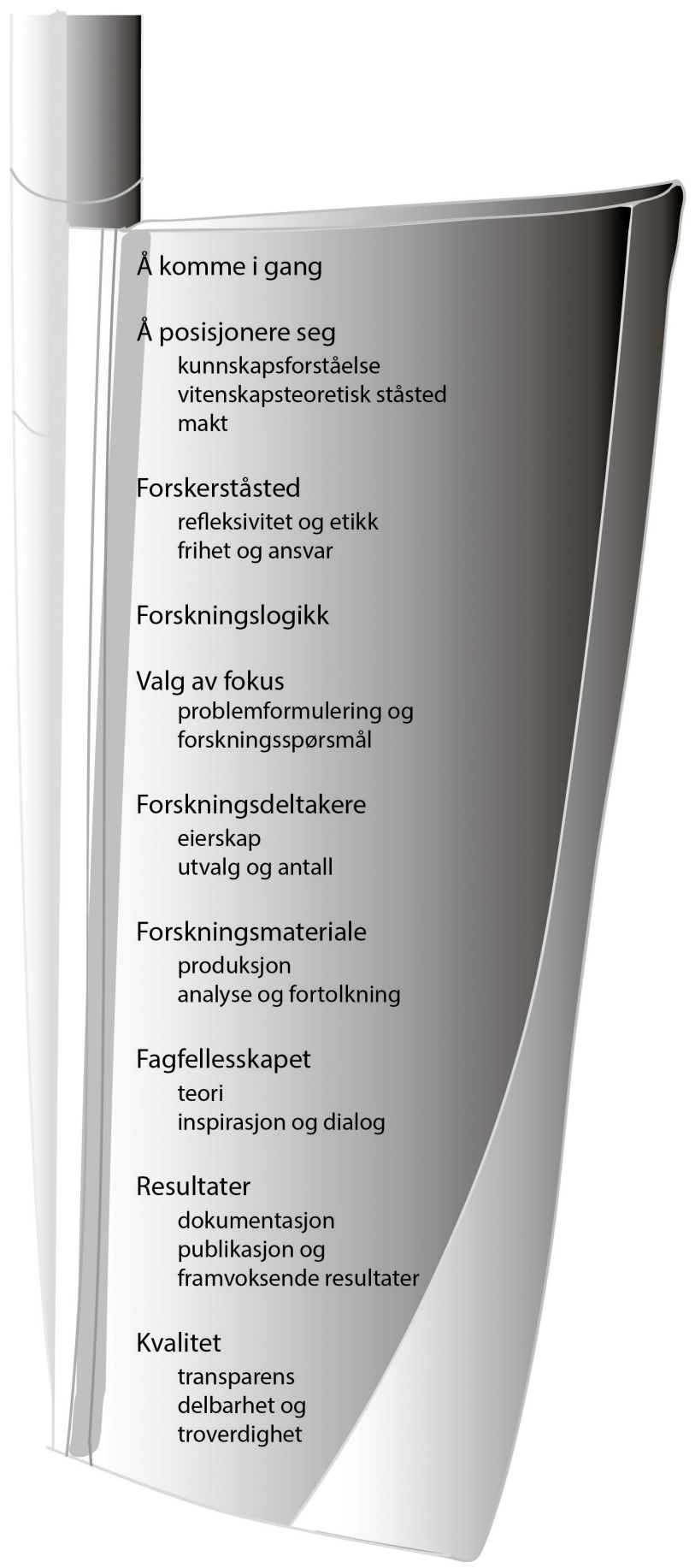

Figur 1. Metodologiske stabiliseringspunkt når man forsker med kunsten. (Visuell design: Mari-Ann Letnes) 


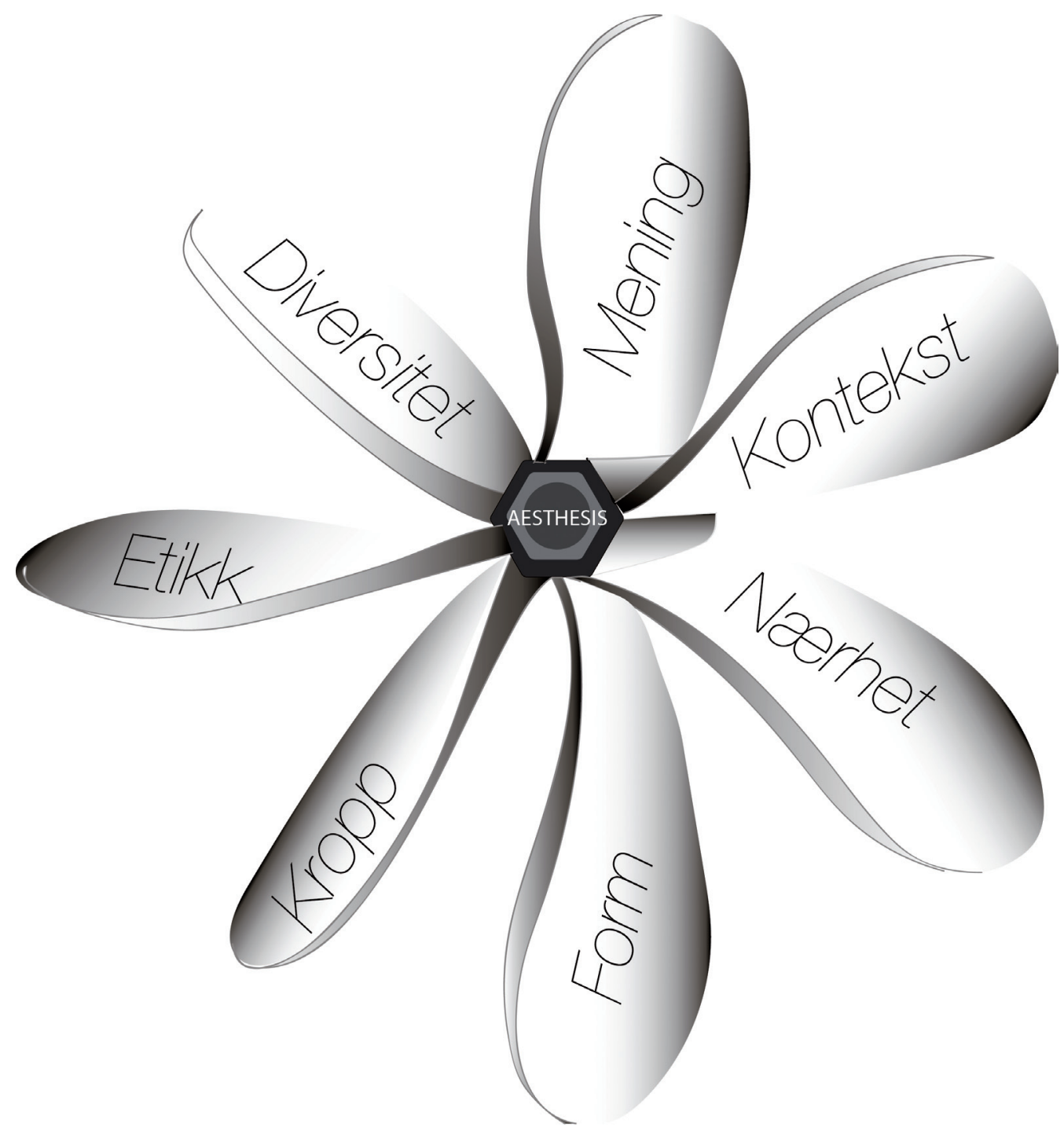

Figur 2. Metodologiske propeller som gir særlig drivkraft, retning og motstand når man forsker med kunsten. (Visuell design: Mari-Ann Letnes)

diversitet i forskningsmetodologisk tilnærming blir viktig. Ulike kontekster trenger å forskes på, eller med, ved hjelp av kontinuerlig utvikling av metoder.

Rekkefølgen på de ulike metodologiske aspektene jeg har valgt her, er slik de erfaringsbasert ofte «viser seg» for meg som dilemmaer eller utfordringer i forskningsprosjekter. Rekkefølgen kan likevel være annerledes; andre forskere kan snuble over disse utfordringene i en annen rekkefølge. Det metodologiske puslespillet kan legges på andre måter, og i en annen rekkefølge, og aspektene jeg trekker fram, 


\section{T. Pernille Østern}

skal ikke forstås som en oppskrift, men en hjelp til å legge sitt eget metodologiske puslespill.

\section{A komme $i$ gang}

En idé til forskning (når man forsker med kunsten) kan starte mer som en følelse, en slags kroppslig kjent nysgjerrighet, enn en klar forskningsidé. Utforskning for å komme i gang kan skje gjennom lek med materialer, improvisasjon med andre, samtaler over en kaffe, vandringer i naturen. Det kan ta lang tid før ideen blir til et konkret forskningsprosjekt. Da jeg var 11 år (i 1982), syklet jeg til skolen en iskald tidlig vintermorgen, sklei på isen, datt av sykkelen og ble liggende på rygg. Over meg bredte den mest fantastiske stjernehimmel seg ut. Der og da oppsto en slags sansning av en begynnende idé til en dag å lage en danseforestilling om universet. Ideen gled i bakgrunnen, summet i kroppen, livet gikk sin gang. Det tok 30 år før ideen skulle lede til et konkret prosjekt. Det kunstneriske og naturfaglige FoU-prosjektet SPACE $\mathrm{ME}^{10}$ ble gjennomført i 2011-2012. Ideen til kunst- og forskningsprosjektet hadde summet i meg i flere tiår før den fant sin form, i møte med en signifikant annen (biolog og naturfagdidaktiker Alex Strømme, sentral forsker sammen med meg i SPACE ME) .

Denne komme-i-gang-fasen er en fase der «anything goes», samtidig som den får gravitasjon og bindes gjennom kunstpraksisens regler og derfor ikke er en fullstendig "alt er tillatt»-periode (jf. Hannula, Suoranta \&Vadén, 2014, s. 5). Andre mennesker, materialer eller kontekster som improvisasjons- og/eller samtalepartnere er ofte signifikante i denne fasen. Det vil si at det å komme i gang ofte er en relasjonell opplevelse og handling.

\section{A posisjonere seg, kunnskapsforståelse, vitenskapsteoretisk ståsted, makt}

Karakteristisk for kunnskapsforståelsen når man forsker med kunsten, er at man, på ett eller annet plan, forstår kunnskap som konstruert, ikke som en essensiell sannhet uavhengig av verdigrunnlag, kropp, kontekst, kultur og samfunn. Valg av vitenskapsteoretisk perspektiv gir forskeren en posisjonering som styrer hva hun eller han ser (eller opplever, sanser). Når man forsker med kunsten, kan vitenskapsteoretisk posisjonering variere avhengig av type studie. Ulike vitenskapsteoretiske posisjoneringer får fram ulike aspekter ved forskningsmaterialet.

Det er viktig å være klar over at valg av vitenskapsteoretisk ståsted innebærer håndtering av makt over forskningsmaterialet og -deltakerne. Forståelse og fortolkning av hva mennesker gjør, sier eller opplever i ulike praksiser, fortoner seg forskjellig avhengig av hvor man ser fra. Dermed gjør behovet for etiske overveielser seg gjeldende også i tilknytning til valg av vitenskapsteoretisk ståsted. Transparens i valg av vitenskapsteoretisk ståsted er altså sentralt når man forsker med kunsten, ikke minst for å vise at man som forsker er klar over den makt man dermed håndterer.

\footnotetext{
${ }^{10}$ Se https://www.ntnu.no/ilu/spaceme (tilgang 24.10.17)
} 
Forskerståsted, refleksivitet og etikk, frihet og ansvar

Det å forske med kunsten har i de aller fleste tilfeller stor nærhet til det man forsker på. Dette fordi det å forske med kunsten nesten alltid setter i sving, eller hviler på, kroppslig kunnskap, hos forskeren selv og/eller hos forskningsdeltakerne. Kropp innebærer nærhet. Kropp eksisterer i kontekst, og kontekst gir også nærhet. En kontekst her kan være det lille bygdekoret som ildsjeler har arbeidet $\mathrm{i}$ årevis for å bygge opp, eller det kan være en større kontekst av for eksempel et nasjonalt nettverk for bygdekor. Det å forske med kunsten handler ofte om formskapende, menings- og mulighetssøkende prosesser. I slike prosesser setter mennesker seg selv på spill, og både mennesker og kontekster blir sårbare. Det å forske med kunsten er dermed nesten alltid nærhetsforskning, der forskerståstedet er nært, og som ofte inneholder innslag av selvstudier (jf. Sinner et al., 2006).

Nærhetsforskning krever høy grad av refleksivitet, og etiske perspektiver blir viktige. Ifølge Anthony Giddens (1991) handler refleksivitet om å legge merke til hva du legger merke til. For den refleksive forskeren innebærer dette aktivt å lete etter en kritisk kobling mellom (estetisk) opplevelse, forståelse og fortolkning. En refleksiv holdning overfor hvor du ser fra som forsker, $i$ hvilken retning du ser og hvorfor, åpner for brudd, (selv)transformasjon, ny forståelse og endring. Ved hjelp av refleksivitet i forskning kan man unngå å videreføre forståelser man tar for gitt eller låse verden i stereotype kategorier og hierarkier. Derfor er refleksivitet også etisk. Ved hjelp av en refleksiv holdning kan forskeren komme opp med kraftfulle motbilder til konvensjonell tenkning og tradisjonelle teorier, og utfordre både seg selv og andre - men den egne forskningen må relateres til andres arbeid, og det egne bidraget må både synliggjøres og diskuteres.

Etiske overveielser trenger å gjennomsyre hele forskningsprosjektet. Grunnleggende handler forskningsetikk om å ikke skade forskningsdeltakere, forskere, kontekster eller miljøer. Høye krav til etiske overveielser henger sammen med at det å forske med kunsten, oftest er nærhetsforskning. Man går tett på, og løper dermed risiko for å skade både andre og seg selv. Forskning kan skade i alle faser: ved utforming av hensikt, ved produksjon av empirisk materiale, ved analyse og drøfting, og ved forskningsformidling. Alle faser trenger derfor etiske overveielser og etiske løsninger. Å få til etiske løsninger griper inn i den formskapende prosessen, altså hvordan kunst- og/eller forskningspraksisen designes og gjennomføres, og det å tenke og handle etisk krever nyskaping/kreativitet (jf. Kara, 2015, s. 35-54). Etikk i forskning henger dermed sammen med kreativitet i forskning, og kreativitet i forskning peker på viktigheten av diversitet og pluralisme i forskning. Ulike forskningsspørsmål krever ulike metodologier, blant annet, og ikke minst, fordi det er ulike etiske dilemmaer knyttet til hvert unike forskningsprosjekt. Å bruke etablerte metodologier kan være direkte uetisk. Dette fordi metodologier ikke er verdinøytrale (jf. vitenskapsteoretiske ståsted), og de har oppstått i sin tid for å brukes til å undersøke problemer som var relevante den gang. Metodologier som ble skapt for å undersøke problemer eller kontekster i første del av 1900-tallet, passer ikke nødvendigvis å bruke i første del av 2000-tallet. Samfunn, menneske- og kunnskapssyn har endret seg. Ikke minst har verden blitt langt mer hørbart flerstemt. Utforming av forskningsmetodologier 


\section{T. Pernille Østern}

trenger å stå i levende relasjon til samfunn, samtid og kontekst, for ikke å låse meningsskaping og fiksere og redusere potensialene i forskningsresultatene (jf. Kara, 2015, s. 14). Det er for eksempel ikke sikkert at skriftlig, språklig dominert forskning (alene) er den etisk beste måten å undersøke menneskers opplevelser (av kunst), siden opplevelser (av kunst) per definisjon er flersanselige.

Denne situasjonen, med stor nærhet og åpenhet for (og ofte nødvendighet av) metodologisk pluralisme, skaper en situasjon der forskeren står i spennet mellom frihet og ansvar. Forskeren må ha valgfrihet og ta de sjanser som trengs for å kunne undersøke det som skal undersøkes. Samtidig må forskeren ta ansvar og være personlig til stede i hvert valg og hver fortolkning som gjøres (jf. Hannula, Suoranta \& Vadén, 2014). For mange forskere innenfor både kvalitativ forskning og det å forske med kunsten, er det ikke lenger nok at forskning ikke skal skade. Isteden ønsker man at forskning skal bidra positivt til personer eller miljøer som blir analysert og forsket på (jf. Kara, 2015). I sin masteroppgave utviklet Karin Andreasson (2017) en didaktisk tilnærming til somatisk dans som hun håpet kunne bidra positivt til kroppsopplevelsen hos personer med MS. Hun er selv utdannet dansepedagog med diagnosen MS, og hun har dermed sterk nærhet til det hun undersøker. Karin er tydelig på sitt ønske om å bidra positivt til forskningsdeltakerne i det hun skriver: «Målet med forskningen er å utvikle en didaktisk tilnærming som har en positiv innvirkning på deltakernes opplevelse av egen kropp, og det er dermed et etisk mål» (Andreasson, 2017, s. 31). Å forske med kunsten kan innebære kraftfulle endringsprosesser, og siden de er kraftfulle, bør de helst være positive. Gjennom å tillate metodologisk diversitet, pluralisme og kreativitet, kan forskning bli etisk ansvarlig.

Forskning kan også skade forskeren. Helen Kara (2015, s. 53) påpeker hvordan dette ofte har fått liten oppmerksomhet innenfor forskningsetikken. Å ta vare på seg selv som forsker, er likevel en viktig del av forskningsetikken når man forsker med kunst, ikke minst fordi det er lettere å fungere kreativt og nyskapende i forskningen når egen velvære er ivaretatt. Man trenger å ivareta både egen sikkerhet når man er ute på feltet/i praksiser, være klar over de sterke emosjonelle prosesser man kan komme til å sette $\mathrm{i}$ gang, få innsyn i og trekkes inn $\mathrm{i}$, samt håndtere den utmattelse man ofte kan oppleve fordi prosessene er nærgående, altoppslukende, sterkt relasjonelle og vanskelige å legge fra seg når man ikke «er på jobb».

\section{Forskningslogikk}

Forskningslogikk handler om med hvilken type logikk man navigerer i et forskningsprosjekt. Tradisjonelt snakker man om enten induktiv (å se fra/starte i praksis/empiri) eller deduktiv (å se fra/starte i teori) forskningslogikk. Abduksjon er en tredje type logikk. Denne plasseres midt imellom induksjon og deduksjon. Min erfaring er at de fleste som forsker med kunsten (og som forsker kvalitativt), forholder seg til en abduktiv forskningslogikk. Begrepet abduksjon kan spores tilbake til den amerikanske filosofen Charles Sanders Peirce (1903/1998). Prefikset ab- er latinsk og betyr «av» (away) eller «bort fra» (away from). Abduksjon er dermed en type forskningslogikk som handler om å la tanker og praksiser «ta av» fra etablerte tankemønster eller etablerte praksiser og 
tillate kunstnerisk-vitenskapelig kreativitet. Den meningssøkende prosessen må vandre fram og tilbake mellom eksisterende teori og kunstneriske praksiser, estetiske opplevelser og erfaringer (jf. Sinner et al. 2006; Hannula, Suoranta \& Vadén, 2014). Noe sted på vegen må man bryte av og ta et sprang inn i ny innsikt. Ph.d.-kandidat Kristian Nødtvedt Knudsen startet sitt ph.d.-arbeid i drama/teater fagdidaktikk med en interesse for å revitalisere dramapedagogikken, og for sosiale medier. Studiens abduktive forskningslogikk innebar en eksplorerende tilnærming til prosjektet, der innsikter kom, og fokus og forskningsspørsmål ble mer og mer spisset gjennom de erfaringer Kristian gjorde gjennom praktiske erfaringer med utvikling av det dramadidaktiske designet \#iLive. Hele tiden pendlet han fram og tilbake i dialog med teori, samtidig som han selv genererte teori. Det dramadidaktiske prosjektet ble kontinuerlig justert samtidig som det vokste fram en abduktivt logisk helhet (Nødtvedt Knudsen, 2017).

Gjennom abduksjon benytter forskeren seg av begrepet guiding principle, veiledende begreper som styrer hvilken retning forskeren ser $i$, siden valgmulighetene er uendelige. Guiding principles kan sammenlignes med det å ha et teoretisk perspektiv å utgå fra, men dette kan med en abduktiv forskningslogikk endres flere ganger undervegs, $i$ en pendlende bevegelse med empiriske/praktiske/kunstneriske erfaringer.

\section{Valg av fokus - problemformulering og forskningsspørsmål}

Fokus når man forsker med kunsten er ofte på personer (subjekter), praksiser (systemer) eller kunstneriske materialer og produkter. Det å forske med kunsten kan for eksempel handle om å undersøke og/eller skape en ekspressiv form som åpner for og muliggiør empatisk deltakelse i andres liv eller i situasjoner som studeres. Forskningsspørsmålene vokser ofte fram fra forskerens kunstneriske og/eller pedagogiske praksis eller personlige liv (Sinner et al., 2006, s. 1238). Med problemformulering mener jeg et overordnet spørsmål som man ønsker å undersøke kreativt og kritisk. Forskningsspørsmål er mer konkrete og forskbare underspørsmål som operasjonaliserer og muliggjør undersøkelse av problemformuleringen. Både problemformuleringer og forskningsspørsmål blir i det å forske med kunsten oftest til undervegs, $\mathrm{i}$ en abduktiv bevegelse i pendling mellom de erfaringer man giør seg i (kunstnerisk) praksis og teori. Masterstudent Anita Waaseth Dahl (2017) undersøkte i sin masteroppgave verdien av et kompetansehevingstilbud i musikk organisert som et samarbeid mellom kulturskole, barnehage og barnehagekontoret i kommunen. Med den første problemformuleringen hun formulerte, slet hun med å komme fram til noe interessant og nytt med studien. Orientering mot ny teori ble et vendepunkt. Ved hjelp av nye teoretiske perspektiver fikk analysearbeidet liv, hun kunne reformulere sin problemformulering og ende opp med et nyskapende kunnskapsbidrag.

Problemformulering og forskningsspørsmål når man forsker med kunsten, er ikke ja-nei-spørsmål, men spørsmål som er åpnende for utforsking, perspektivtaking, forståelse og meningsskaping. Å formulere en fungerende problemformulering og «presise» forskningsspørsmål er ofte en langvarig og emosjonelt ladet prosess. Man må vri til mer og mer, spisse, endre, kjenne etter, forkaste og starte på nytt, helt til 


\section{T. Pernille Østern}

spørsmålet/spørsmålene - (kunstnerisk) praksis - teori - (kunstnerisk) kontekst danner en helhet, et puslespill som henger sammen.

\section{Forskningsdeltakere - eierskap, utvalg og antall}

Deltakere som involveres i prosjekter der man forsker med kunsten, forstås som forskningsdeltakere og -subjekter, eller til og med medforskere, mer enn som informanter eller forskningsobjekter. Forskeren selv er ofte både prosjektleder og forskningsdeltaker på en og samme gang. Forskningsdeltakerne (inklusive forskeren) involveres ofte dypt i kunstneriske eller estetiske prosesser, gir av seg selv, og anonymisering er ofte ikke mulig - eller ønsket. Flere ganger når jeg har involvert profesjonelle kunstnere i forskningsprosjekter, har de spesifikt påpekt at de ikke ønsker å anonymiseres, fordi det de sier/gjør, henger sammen med deres kunstnerskap som de vil skal tilskrives dem. I samtykkeskjemaer skriver jeg da sammen med kunstnerne inn at de ikke skal anonymiseres, men at de skal få lese, bidra til og godkjenne analyser og fortolkninger før de publiseres. Her oppstår også et finmasket og komplekst nett av eierskap til forskningsmaterialet, der kunstneres eierskap til eget åndsverk (jf. åndsverksloven ${ }^{11}$ ) møter forskningsetiske retningslinjer (jf. forskningsetiske retningslinjer ${ }^{12}$ ) i en sammensmeltning som må bygge på tillit, dialog og respekt. Retten til når som helst å kunne trekke seg ut av et forskningsprosjekt, gjelder i all forskning. Det kan likevel ha alvorlige konsekvenser for et forskningsprosjekt der man forsker med kunsten hvis en deltaker trekker seg ut, siden skillet mellom kunst og kunstner, forsker, forskningsdeltaker og forskningsmateriale ofte er svært vanskelig å trekke. Hvis en sentral forskningsdeltaker trekker seg ut, kan det gjenstå svært lite å forske på. Det å forske med kunsten har dermed best levekår som relasjonell forskning, der man gjennomgående jobber for en god dialog og der valg tas av forsker sammen med forskningsdeltakere i gjensidig forståelse og med respekt for personlig og kunstnerisk integritet. Samtidig må forskeren kunne beholde sin integritet som forsker.

Utvalg av forskningsdeltakere kan skje på ulike måter, avhengig av type prosjekt og hva som er praktisk mulig. Det samme gjelder antall deltakere. Alt fra en til flere personer, praksiser, miljøer eller prosesser kan inngå i prosjektet. Som regel er likevel antallet personer eller praksiser som studeres relativt lite, fordi forskningen er prosessuell og søker mot forståelse og nye perspektiver mer enn oversikt og kvantiteter.

\section{Forskningsmateriale - produksjon, analyse og fortolkning}

Forskningsmateriale når man forsker med kunsten produseres ofte i kollaborative og estetiske prosesser ved hjelp av et rikt spekter metoder. Med metoder mener jeg et konkret nivå som det metodologiske nivået omslutter. Det finnes to typer metoder: metoder for å produsere forskningsmateriale og metoder for å analysere forskningsmateriale. Når man forsker med kunsten, må begge typer metoder utvikles

\footnotetext{
${ }^{11}$ https://lovdata.no/dokument/NL/lov/1961-05-12-2 (tilgang 04.08.2017)

${ }^{12} \mathrm{https}: /$ www.etikkom.no/forskningsetiske-retningslinjer/Samfunnsvitenskap-jus-og-humaniora/ (tilgang 04.08.2017)
} 
fra prosjekt til prosjekt. Konkrete metoder for å produsere forskningsmateriale kan være kunstneriske eller kunstpedagogiske praksiser, ulike former for intervjuer, intervensjoner, utviklingsarbeider, kunstneriske og/eller multimodale uttrykk, et bredt spekter av tekster, felt- og refleksjonsnotater, digitale materialer, arbeid med ulike materialer, ulike former for observasjoner, inklusive deltakende observasjon og andre metoder som enda ikke er utviklet.

Utvikling av metoder for å produsere forskningsmateriale når man forsker med kunsten, befinner seg i et liminalt rom midt imellom to tradisjoner: kunsttradisjoner og forskningstradisjoner (Sinner et al., 2006, s. 1229). Begge tradisjonene har utviklet seg over lang tid og inneholder syn på hva som er "god kunst» og hva som er "god forskning». Når man forsker med kunsten, må disse på ett eller annet vis smelte sammen, ofte ikke uten kollisjoner og produktive gnisninger, og hva som fungerer, må kvalitetssikres og avgjøres fra prosjekt til prosjekt. Man står hele tiden i dialog med etablert kunstpraksis på det aktuelle fagfeltet, og det kreves kjennskap til denne, samt med metoder andre har brukt for å produsere forskningsmateriale når de forsker med kunsten.

Analyse og fortolkning er ofte det punktet i forskningsprosessen der man spør seg: Hva giør jeg nå, med dette materialet jeg har produsert? Både i det å forske med kunsten og i kvalitativ forskning, opptrer forskningsmaterialet som en egenrådig aktør som disiplinerer forskerens kreativitet (Rennestam \& Wästerfors, 2015). I denne fasen blir det veldig tydelig at det ikke bare er forskeren som har makt over materialet, men at materialet har makt over forskeren. Et forskningsmateriale kommer med tilbud, affordanser (Gibson, 1986, s. 127), og man kan ikke gjøre hva som helst med det. Analysefasen handler likevel om på ett eller annet vis å sortere i materialet, redusere mengden av forskningsmateriale og argumentere - kunstnerisk, multimodalt og skriftlig - for de resultater som vokser fram (Rennestam \& Wästerfors, 2015). Når man forsker med kunsten, krysses og blandes analysemetoder, nye utvikles og hybrider oppstår, styrt av forskningsprosjektets hensikt (Savin Baden \& Howell Major, 2013; Sinner et al., 2006). Ofte kan analysen skje i form av bricollager, assemblager og montasjer. I disse kommuniseres ulike formspråk som er aktivert i forskningsprosjektet som sidestilte analyser som benytter seg av ulike modaliteter, for eksempel både skriftlig tekst og visuelle uttrykk. De trenger å stå side ved side fordi de ikke fullstendig kan oversettes til hverandre, for mye går "lost in translation" (jf. Hannula, Suoranta \& Vadén, 2014). Masterstudent Emma Sigridsdatter Jones utviklet et kunstnerisk utviklingsprosjekt der hun selv var kunstner og forsker-lærer (Jones, 2015). Metodene Emma utviklet for å produsere forskningsmateriale, var å skape en teaterforestilling for barn, observasjon, intervju, en pre-/postprøve og forskerlogger. For å kunne analysere materialet på en måte som beholdt kompleksiteten og de ulike forståelsesformene, trengte hun å behandle de ulike materialene ulikt. Hun utviklet dermed en overordnet multimodal analyse. Sammen orkestrerte de ulike delanalysene multimodal mening som et resultat av prosjektet. Analysen var kompleks, men beholdt og fikk fram betydningen av nettopp det multimodale i den fabelfaktiske læringen og undervisningen. 


\section{T. Pernille Østern}

Når man forsker med kunsten, er det særlig viktig å være oppmerksom på både innhold og form i materialet, og disse bør sees i sammenheng. Det analytiske blikket (eller den analytiske kroppen, sansningen) trenger å være oppmerksomt, tilstedeværende, generøst, åpent, langsomt og nøyaktig, fordi det hviler på aesthesis - det estetiske - som åpner for en følelse av berøring. I det analysen ikke lenger kjennes, og gir en følelse av berøring, eller tangerer en estetisk opplevelse, kan man spørre seg om man har gått bort fra det å forske med kunsten.

\section{Fagfellesskapet - teori, inspirasjon og dialog}

Dialog med aktuelt fagfellesskap i form av teori og andres kunstarbeid er viktig når man forsker med kunsten. Dette gjelder dialog med både fagteori, andres kunstneriske praksiser, samt metodologisk teori knyttet til det å forske med kunsten. Forholdet til teori er likevel oftest slik at man går $i$ dialog med teori, mer enn at man baserer seg på teori (jf. Savin Baden \& Howell Major, 2013, s. 302). Resultatet kan også være teorigenererende eller teoretiserende. Man produserer sjelden en teori som forklarer et lokalt fenomen (slik som ved grounded theory), og man bruker sjelden hypoteser som man tester ut (som i mye kvantitativ forskning). Isteden går man i dialog med, lar seg inspirere av, forholder seg kritisk til, og/eller bygger videre på, eksisterende relevant teori, fagorientert og/eller metodologisk orientert. Når man forsker med kunsten, er teoretiske perspektiver sjelden klare fra start, siden fokus er på utforskning (Sinner et al., 2006, s. 1238). Man ledes gjennom en abduktiv forskningslogikk fram og tilbake mellom mulige teoretiske perspektiver og meningssøkende praksis.

Det er viktig å referere til andres teoretiske og/eller kunstneriske arbeider for å vise at man er bevandret på området. Verken kunst eller forskning opererer i et vakuum, men i et fagfellesskap der man sakte, men sikkert, skaper ny kunst og bygger ny kunnskap. Å referere til andres arbeid i form av dialog med eksisterende kunst og teori, er en særlig utfordring for det å forske med kunsten. Ideen om den autonome kunstneren som kun henter inspirasjon fra sitt eget geni, henger som en tung tradisjon over feltet. Mangelen på kjennskap til, eller interesse for, eksisterende forskning og forskningsmetodologi kan noen ganger være slående innenfor særlig kunstnerisk forskning. Dermed fremstår forskere med kunst av og til som uvitende, og av og til ignorante, i det de for eksempel kaller noe de har gjort «helt nytt», i stedet for å ha kontekstualisert seg selv som en del av et felt som har vært i utvikling lenge. Hannula, Suoranta \& Vadén (2014, s. 10) skriver «When doing research, however lost and lonely [...] please, please, please do not be afraid of influences», og videre:

Research is propelled by knowing your own history and being curious about and interested in it - not because of altruistic reasons but due to the fact that without this involvement there will be no context, no platform, no trampoline; there will be no sites and situations of give and take, push and pull. Without this acute sense and sesnsibility, with the reinterpretation and even re-enactment of the past as a plural entity, what else is there? (Hannula, Suoranta \& Vadén, 2014, s. 11) 


\section{Resultater - dokumentasjon, publikasjon og framvoksende resultater}

Dokumentasjon og publikasjon av forskning der man forsker med kunsten, er ofte kreativ og nyskapende og består ofte, men ikke alltid, av både kunstneriske eller multimodale resultater/publikasjoner og skriftlig tekst. Dokumentasjon og publikasjoner er like ulikeartede i sin form som metodologiene som utvikles undervegs, siden hensikt-metodologi-resultat-publikasjon henger sammen. I prosjektet Dansepedagogens kroppslige kunnskap undersøkte jeg sammen med dansepedagogene Mari og Ingeborg på hvilke måter deres praktisk-pedagogiske kunnskap som dansepedagoger var kroppslig. Jeg produserte et teoretisk resultat i form av en artikkel, mens Mari ${ }^{13}$ og Ingeborg ${ }^{14}$ skapte koreografier, der de undersøkte og uttrykte hvordan deres praktiskpedagogiske kunnskap er kroppslig. Dansepedagogenes koreografier og min artikkel står som sidestilte forskningsresultater uttrykt i ulike modaliteter, der de begge står $i$ et avhengighetsforhold til hverandre, samtidig som både koreografier og artikkel kan oppleves/leses hver for seg. Det koreografiene bidrar med, er særlig de affektive og dynamiske sidene ved pedagogenes kroppslige praktisk-pedagogiske kunnskap. Artikkelen er på sin side produktiv i å teoretisere rundt hvordan Maris og Ingeborgs tenkning og handling som lærere er kroppslig.

\section{Kvalitet, transparens, delbarhet og troverdighet}

Å diskutere og sette ord på hva kvaliteten i et forskningsarbeid består av, er viktig, men krevende, ikke minst når det gjelder å forske med kunsten. Siden feltet åpner for metodologisk pluralisme, finnes det heller ikke ett enkelt sett med kriterier for å vurdere kvalitet. Forskning trenger å være både transparent, delbar og troverdig for å kvalifisere som forskning, enten dette handler om å forske med kunsten eller annen forskning. Etiske perspektiver må være ivaretatt. Med transparens menes at metodene som er brukt er synlige, gjort rede for og at valg av metoder har en begrunnelse. Transparensen trenger å være der i alle ledd. Forskning skal kunne deles med, utfordres av og kritiseres av andre, også når man forsker med kunsten.

Når man forsker med kunsten, blir troverdigheten arbeidet med kontinuerlig, siden prosessen er levende, dynamisk og det meste kan endre seg undervegs. Det finnes få regler for når et forskningsprosjekt blir troverdig som forskning når man forsker med kunsten; det er mye som kan være tillatt så lenge «det funker» gjennom en slags logikk som blir synlig (kjennbar) og forståelig for andre. Kunstnerisk forskning i musikk kan være troverdig når det svinger - eller når det ikke svinger. Alt avhenger av hensikt og av kunstnerisk og språklig troverdig argumentasjon for de valg man har tatt. Troverdigheten oppstår når helheten fungerer og henger sammen og de ulike delene og valgene blir synlige eller kjennbare, og forståelige, og når forskningen på ett eller annet vis berører (jfr. aesthesis). Evaluering av kvalitet når man forsker med kunsten, kan handle mer om verdsetting enn evaluering i tradisjonell

\footnotetext{
${ }^{13}$ Maris koreografi https://vimeo.com/40433953 (tilgang 23.10.2017)

${ }^{14}$ Ingeborgs koreografi https://vimeo.com/40075211 (tilgang 23.10.2017)
} 


\section{T. Pernille Østern}

forstand (Sinner et al., 2006, s. 1252). Det kan også være verdt å endre spørsmål fra «Er dette god forskning med kunsten?» til «Hva er denne forskningen med kunsten god for - hva er det den gjør, produserer, hvordan berører den (eller ikke)?» (jfr. Sinner et al., 2006. s. 1252).

\section{En sammenfattende kommentar}

I denne artikkelen har jeg brukt min egen erfaring som forsker-kunstner og veileder kombinert med lesning av eksisterende metodologisk teori og praksiser til å undersøke forskningsspørsmålet Hvordan kan det å forske med kunsten som metodologisk praksis få form og drivkraft gjennom å forstå aesthesis som mandat?

Gjennom å tegne opp metodologiske stabiliseringspunkt som trenger overveielser, samt propeller som særlig gir drivkraft, retning og motstand når man giør sine metodologiske overveieleser når man forsker med kunsten, har jeg forsøkt å svare på forskningsspørsmålet. Selve forskningsspørsmålet har jeg formulert undervegs i en abduktiv prosess. Denne artikkelen er et erfaringsbasert og teoretisk forsøk på både å stabilisere og skape bevegelse i forståelsen av det å forske med kunsten. Jeg forsøker å bidra til kartlegging, artikulering, utvikling og stabilisering av et metodologisk terreng som ikke er ferdig etablert, men i stadig tilblivelse, og som har mye å bidra med til forskning, samfunn og samtid.

Det å forske med kunsten får metodologisk stabilitet gjennom å trekke forbindelser til det mer etablerte feltet for kvalitativ forskning - et felt som selv har vært i formidabel endring og ekspansjon ikke minst under påvirkning av arts-based og artistic research de seneste tiårene (jf. Kara, 2015; Roar, 2016; Savin-Baden \& Howell, 2013). Samtidig får det å forske med kunsten sin egen, mer unike metodologiske dynamikk gjennom forsøksvis å skrive fram propeller som særlig gir metodologisk kraft, retning og motstand når man forsker med kunst. Disse har jeg her artikulert som form, mening, nærhet, kropp, kontekst, etikk og diversitet, alle utspring av aesthesis. Kombinasjonen meningssøkende og formskapende prosesser i ulike modaliteter, kroppslig og dermed personlig kunnskap, i ofte små og sårbare kontekster, framtvinger etiske overveielser og åpenhet for metodologisk diversitet og pluralisme som noe av det aller mest sentrale når man forsker med kunsten. Det å forske med kunsten kan dermed gi - blant annet - følgende metodologiske innsikter tilbake til et bredt felt for kvalitativ og post-kvalitativ forskning:

- forståelse for form og innhold som ulike sider av samme mynt

- ulike modaliteters unike affordanser (tilbud om mening) som ikke lar seg oversette fra modalitet til modalitet uten at noe går tapt, samtidig som noe nytt vinnes

- den transformative kraften i menings- og mulighetssøkende prosesser

- den kroppslige kunnskapens sentrale betydning for opplevelse, læring og empatisk forståelse

- verdien av nærhet i forskning 


\section{Å forske med kunsten som metodologisk praksis med aesthesis som mandat}

- kontekstens betydning og små konteksters sårbarhet

- betydningen av metodologisk diversitet og pluralisme for rik meningsskaping

- etiske overveielser som helt sentrale i alle ledd av et forskningsprosjekt, og etikk og kreativitet i forskning som mulighetsskapende støttere av hverandre for å unngå reduksjonistiske (eller kolonialistiske) forskningsresultater.

Når man forsker med kunsten, er dette innsikter man forsøker å ikke redusere bort gjennom å tvinge metoder eller metodologier ned over kunstneriske eller estetiske praksiser som ikke fungerer hvis man ønsker å beholde kompleksiteten og rikdommen i slike praksiser. Metodologi skal ikke fungere reduserende på mening (kun på omfang av forskningsmateriale). Denne motstanden mot meningsreduksjon er et viktig bidrag fra det å forske med kunsten til et bredt kvalitativt forskningsfelt, en produktiv og berikende motstand som får sin næring av at det å forske med kunsten blir stående i og får sitt mandat av aesthesis. Jeg håper denne artikkelen kan bidra til at forskerstudenter og forskere kan skape både stabilitet og bevegelse i egen framtidig forskning med kunsten, slik at det å forske med kunsten kan bidra produktivt på et bredt forskningsfelt, på kunstfeltet, i utdanning og samfunn.

\section{Forfatterpresentasjon:}

Tone Pernille Østern, (Dr. of Arts in Dance) har doktorgrad fra Teaterhögskolan ved Kunstuniversitetet i Helsinki. Hun er dansekunstner/koreograf på det frie scenekunstfeltet og fra år 2016 professor i kunstfagdidaktikk med vekt på dans ved Institutt for lærerutdanning, NTNU (førsteamanuensis år 2009-16). År 2011 var hun skapende fylkeskunstner i Sør-Trøndelag fylkeskommune. Ved Institutt for lærerutdanning er hun fagseksjonsleder for Kunstfag, kroppsøving og idrett, der hun også er fagansvarlig for mastergraden i kunstfagdidaktikk. Hun har høy aktivitet som kunstner-forsker og veileder kontinuerlig master- og ph.d-studenter. Se https://www.ntnu.no/ansatte/tone.pernille.ostern, https:/www.ntnu.no/ilu/200milliarder, https://www.ntnu.no/ ilu/spaceme, www.dance-company.no, www.danselaboratoriet.no

\section{Referanser:}

Academy of Finland (2009). Research in Art and Design in Finnish Universities. Evaluation Report. Publications of the Academy of Finland 4/09. Nedlastet fra http:/www.aka.fi/globalassets/awanhat/documents/ tiedostot/julkaisut/04_09-research-in-art-and-design.pdf (tilgang 09.11.2017)

Andreasson, K.M. (2017). A bli venn med kroppen gjennom dans. Muligheter ved somatisk dans for en positiv kroppsopplevelse hos personer med MS. (Masteroppgave). Trondheim: NTNU Norges teknisk-naturvitenskapelige universitet.

Barone, T. \& Eisner, E. (2012). Arts Based Research. Thousand Oaks, California: SAGE

Bresler, L. (1994). What Formative Research Can Do for Music Education: A Tool for Informed Change. The Quarterly fournal of Music Teaching and Learning, 3, (14), 11-24.

Bresler, L. (2006). Toward Connectedness: Aesthetically Based Research and its Ethical Implications. Studies of Art Education. A Fournal of Issues and Research 2006, 48 (1), 15.

Dahl, A.W. (2017). Musikkveiledning i barnehage. Kulturskolen som lokalt ressurssenter. (Masteroppgave). Trondheim: NTNU Norges teknisk-naturvitenskapelige universitet.

Gibson, J.J. (1986). The ecological approach to visual perception. New York: Psychology Press Taylor \& Francis Group.

Giddens, A. (1991). Modernity and Self-Identity: Self and Society in the Late Modern Age. Cambridge: Polity Press. 


\section{T. Pernille Østern}

Hannula, M., Suoranta, J. \& Vadén, T. (2014). Artistic Research Methodology. Narrative, Power and the Public. New York: Peter Lang.

Jones, E.S. (2015). Fabelfaktisk laring og undervisning. Et multimodalt og kunstnerisk undervisningsdesign med naturfaglig tema på barneskoletrinnet. (Masteroppgave). Trondheim: NTNU Norges teknisk-naturvitenskapelige universitet.

Kara, H. (2015). Creative Research Methods in the Social Sciences. A Practical guide. Bristol and Chicago: Policy Press.

Klein, J. (udatert webpublikasjon). What is artistic research? FAR fournal for Artistic Research. Nedlastet fra http://www.jar-online.net/what-is-artistic-research/ (Tilgang 03.08.2017).

Nelson, R. (red.) (2013). Practice as Research in the Arts. Principles, Protocols, Pedagogies, Resistances. Hampshire og New York: Palgrave Macmillan.

Nødtvedt Knudsen, K. (2017). \#iLive - konturer af en performativ dramadidaktik $i$ en digital samtid. (Diss.). Trondheim: NTNU Norges teknisk-naturvitenskapelige universitet.

Orning, T. (2017). Music as performance - gestures, sound and energy. A discussion of the pluralism of research methods in performance studies. Fournal of Research in Arts and Sports Education, Special Issue: "Å forske med kunsten", Vol. 1, 2017, pp. 79-94.

Peirce, C.S. (1903/1998): The Essential Peirce. Selected Philosophical Writings. Vol.2. Edited by the Peirce Edition Project. Bloomington and Indianapolis: Indiana University Press.

Rasmussen, B. (2012). Kunsten å forske med kunsten. Et blikk på kunnen utfra praksis-teori-relasjonen. I R.G. Gjørum \& B. Rasmussen (red.), Forestilling, framføring, forskning. Metodologi i anvendt teaterforskning (s. 23-49). Trondheim: Akademika.

Raes, G. W. (2014). Experimental Art as Research. I D. Crispin \& B. Gilmore (red.), Artistic Experimentation in Music, An Anthology (s. 55-60). Leuven: Leuven University Press.

Redding-Jones, J. (2005). What Is Research? Methodological Practices and New Approaches. Oslo: Universitetsforlaget.

Rennestam, J. \& Wästerfors, D. (2015). Från stoff til studie. Om analysarbete $i$ kvalitativ forskning. Lund: Studentlitteratur.

Roar, P. (2016). Kunstnerisk forskning og morgendagens dans: utprøving og refleksjon for utvikling av ny innsikt og praksis. I S. Ø. Svendal (red.), Bevegelser. Norsk dansekunst i 20 år (s. 309-319). Leikanger: Skald.

Sannino, A., Engeström, Y. \& Lemos, M. (2016). Formative Interventions for Expansive Learning and Transformative Agency. Fournal of Learning Sciences, 25 (4), 599-633.

Savin-Baden, M. \& Howell Major, C. (2013). Qualitative research. The essential guide to theory and practice. London and New York: Routledge.

Sinner, A., Leggo, C., Irwin, R.L., Gouzouasis \& Grauer, K. (2006). Arts-Based Educational Research Dissertations: Reviewing the Practices of New Scholars. Canadian fournal of Education, 29, 4 (2006), 1223-1270.

Smith, H. and Dean, R.T. (2009). Practice-led Research, Research-led Practice in the Creative Arts. Edinburgh: Edinburgh University Press.

Steen-Olsen, T. \& Postholm, M-B. (2009). Å utvikle en lcerende skole. Aksjonsforskning og aksjonslcering $i$ praksis. Kristiansand: Høyskoleforlaget.

Ölme, R. (2017). How Artistic Resarch Becomes Public. Nordic Fournal of Dance - practice, education and rese$\operatorname{arch}, 8(1), 40-42$.

Østern, T.P. \& Letnes, M-A. (2017). Et temanummer som undersøker hva det innebærer å forske med kunsten. Fournal of Research in Arts and Sports Education, Special Issue: «Å forske med kunsten» Vol. 1, 2017, 1-6. http://dx.doi.org/10.23865/jased.v1.1082.

\section{Digitale referanser:}

ADiE Artistic Doctorates in Europe https:/www.artisticdoctorates.com/ (tilgang 04.08.2017)

Doktorgradsprogrammet for Artistic Research ved Kunstuniversitet i Helsingfors, http://www.teak.fi/About_ the_programme (tilgang 27.09.2013)

Forskningsetiske retningslinjer, https://www.etikkom.no/forskningsetiske-retningslinjer/Samfunnsvitenskapjus-og-humaniora/ (tilgang 04.08.2017)

FoU-prosjektet SPACE ME, https://www.ntnu.no/ilu/spaceme (tilgang 24.10.2017)

Ingeborgs koreografi https://vimeo.com/40075211 (tilgang 24.10.2017) 


\section{A forske med kunsten som metodologisk praksis med aesthesis som mandat}

Kunstprosjektet SPACE ME, https:/www.dance-company.no/space-me-2012 (tilgang 03.08.2017)

Kunstuniversitetet i Helsingfors, www.uniarts.fi (tilgang 22.10.2017)

Maris koreografi https://vimeo.com/40433953 (tilgang 23.10.2017)

Oxford dictionary, http://www.oxforddictionaries.com/definition/english/aesthetic (tilgang 24.09.2013)

Program for kunstnerisk utviklingsarbeid, http://artistic-research.no/?page_id=12 (tilgang 27.09.2013)

Åndsverksloven, https://lovdata.no/dokument/NL/lov/1961-05-12-2 (tilgang 04.08.2017) 